To be more specific I would suggest the following definition:

Ice island

An elevation of the sea bed, not within the confines of an ice shelf, permanently capped with ice projecting above sea-level but with no rock visible above sea-level.

The term "ice-capped island" would be largely a descriptive term because, cartographically, this feature would be regarded as an ordinary island.

Following the S.C.A.R. decision to use the prefix "sub-glacial" before ordinary generic terms to designate features which are beneath Antarctic ice, it should be pointed out that Diagram (4) illustrates a "sub-glacial island." However, until seismic ice-depth determinations are carried out, such a fact will not be known. One would expect, therefore, that as exploration proceeds some "ice islands" will be reclassified as "sub-glacial islands" for cartographic purposes, although for descriptive purposes the name "ice islands" would probably be retained.

Antarctic Division,

Department of External Affairs, Melbourne, Australia

6 February $196 I$

Phillip LaW

\title{
REFERENGE
}

I. Armstrong, T., and Roberts, B. Illustrated ice glossary. Polar Record, Vol. 8, No. 52, 1956, p. 4-12.Armstrong, T. The recording and reporting of floating ice. Polar Record, Vol. 9, No. 6o, 1958, p. 184-9o.

Sir,

\section{Terminology for Antarctic ice features}

P. G. Law raises an interesting and important point in regard to the nomenclature of ice features, which I most heartily endorse.

The use of the term "ice island" is perhaps a bit unfortunate, but there was a justification if the alternate definition of an island is considered-something set distinctly apart from its surroundings. I do not particularly like the term iceberg which to me represents a portion of a glacier discharged into the sea, instead of a portion of an ice shelf which has broken loose. Though a descriptive term such as "shelf berg", or "shelf island" might be coined, it is a bit too late, for the unfortunate T-3 has now been grounded for nearly a year and is slowly disintegrating. I would much prefer the title "floating ice island" and would argue that these are so few that the extra title is unimportant.

Perhaps to complicate the issue of Law's ice islands, there is Roosevelt Island on the Ross Ice Shelf, surrounded not by the sea in a strict sense but by a floating ice shelf. Also Law's "ice islands" may in time become either "islands," or "islands (ice capped)," or the ice of ice islands may even become detached, in which case the ice island title would be more apt to follow the original ice than the underwater shoal that remained.

The troubles with ice feature definitions come from lack of knowledge of details and with the possibility of temporal changes. The former in many instances may never be resolved, and the latter is a threat that must be lived with. The solution lies in simple terms, and I am very much in favor of Law's suggestions of "ice islands," and would also include such features as Roosevelt Island (Roosevelt Ice Island). When and if the rock above sea-level becomes exposed either artificially or naturally, or is proven by geophysical means to be above sea-level, the term "ice" could be dropped. If the ice as a whole became detached the term "floating" could be added. My understanding of the sub-glacial prefix concept was that it would be mainly applicable to large sub-continent geographical provinces such as plateaus, ranges, channels, etc. It need not confuse the isolated island issue.

2400 Igth Street, N.W.,

Washington 9, D.C. 27 April 196I

A. P. CRary

SIR,

Terminology for Antarctic ice features

We have read with interest the letters on this subject by Mr. Law and Mr. Crary, and fully agree with their views about the need for continued revision and extension of the terms and definitions of Antarctic ice features.

Mr. Law's illustrations of four types of island illustrate the problem well. His types (I) and (2) call for no comment, either in definition or term. However, we suggest that his remarks on types (3) and (4) 
over-simplify the problem. Both types occur and need descriptive terms, but we think great confusion will arise if the term "ice island" is adopted for yet another kind of feature. "Ice island" was used widely for icebergs by visitors to the Southern Ocean during the late eighteenth and early nineteenth centuries. This usage had been dropped by about 1840 , but the term was re-introduced in 1946 for the large low floating tabular bergs which have been found in the Arctic Ocean.

It seems to us that, despite its unsuitability, the latter use is now firmly established, especially in Canada and the United States. The literature on Arctic ice islands is extensive. Experience has already shown that attempts to alter this term, as suggested by Mr. Law, are unlikely to gain general agreement. It also seems essential to avoid quite different meanings in the Arctic and Antarctic.

Mr. Law considers the terms "ice rise" unsuitable for the Antarctic features which he describes (and we agree with him) but he appears to have overlooked the fact that "ice rises" are quite different from any of the features he describes. The suggested definition of "ice rise" (Armstrong and Roberts, 1956, p. 7) is: "A mass of ice resting on rock and surrounded either by an ice shelf, or partly by an ice shelf and partly by sea and/or ice-free land. No rock is exposed and there may be none above sea-level. Ice rises often have a dome-shaped surface. The largest known is about $100 \mathrm{~km}$. across." Roosevelt Island, mentioned in Mr. Crary's letter, is a typical example. Similar features, well in from the ice front, are very common in the area south and west of Alexander Island and in the ice shelf south and east of Thurston Peninsula on the Eights Coast. It seems, in fact, that these features are likely to be discovered and mapped in increasing numbers. The larger ones will certainly have to be given individual placenames. The problem is not confined to the Antarctic, as is shown by Hattersley-Smith (1956). A more recent paper by the same author dealing with the Ward Hunt Ice Shelf in northern Ellesmere Island exemplifies the ambiguity in one sentence: "The ice island formed by the breaking away of the ice shelf in this area..." He is referring to the floating feature, not to the residual ice-covered island. An "ice rise" can, of course, become an "ice island" (in the sense proposed by Mr. Law) if the ice front breaks back far enough to leave it entirely surrounded by water. Mr. Crary also recognizes this possibility, but does not discuss the term "ice rise."

For these reasons, we suggest that while the simple generic terms "island" and "ice rise" are sufficient for use in place-names, there is need for further terms (not to be compounded in place-names) to distinguish Mr. Law's types of ice-covered island. There is, incidentally, at least one more distinct stage of Mr. Law's types (3) and (4), illustrated by Wright and Priestley (1922), in which the ice dome is continued out to sea by a flattened selvage of floating ice. All these are subject to temporal change, in addition to the difficulties of precise visual recognition. How, for instance, is one to distinguish between Mr. Law's type (3) and a grounded berg of similar aspect? It is perhaps indicative that the Russiansnormally addicted to fine distinctions - use only one term, ledyanaya kupola, for both "ice rise" and Mr. Law's islands of types (3) and (4) (Dolgushin, 1958). We hesitate to suggest terms, as distinct from descriptions, at this early stage of investigation. It is first desirable that others should comment on Mr. Crary's willingness to alter the term "ice island." If this could find general support, we think it provides the best solution.

Scott Polar Research Institute, Cambridge

Terence Armstrong BRIAN ROBERTS

\section{REFERENCES}

Armstrong, T., and Roberts, B. Illustrated ice glossary. Polar Record, Vol. 8, No. 52, 1956, p. 7.

Armstrong, T., and Roberts, B. Hlustrated ice glossary. Polar Record, Izvestiya Akademii Nauk SSSR. Seriya Geograficheskaya [News of the Academy of Sciences of the U.S.S.R. Geographical Series], 1958, No. 6, p. 20.

Hattersley-Smith, G. Definition of "ice rise." Polar Record, Vol. 8, No. 52, 1956, p. 66. [Letter.]

Wright, C. S., and Priestley, R. E. Glaciology. London, Harrison, 1922, p. 148. (British (Terra Nova) Antarctic Expedition, 1910-13.)

SIR, Ice thickness variations at an advancing front, Coleman Glacier, Mt. Baker, Washington

For a decade prior to a hot, dry Summer in 1958 , most glaciers in the north-western United States increased in volume. ${ }^{\mathrm{I}}$ 2, 3 Measurements were made during this period at the Coleman Glacier on Mt. Baker, Washington, and the resulting data indicate interesting relationships between ice flow and ice thickness. The ice flow is apparently not proportional to the thickness or gradient.but may depend on a 